\title{
Osmanlı Askerî Eğitiminde Modernleşme Çabaları: Kasımpaşa Bahriye Askerî Rüşdiye Mektebi*
}

\section{Modernization Efforts in Ottoman Military Education: Kasımpaşa Naval Secondary School}

\author{
Mehmet Korkmaz ** (]
}

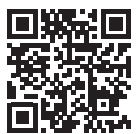

"Bu makale, 3-5 Mayıs 2019 tarihlerinde İstanbul'da gerçekleștirilen Osmanlı İstanbul'u Uluslararası Sempozyumu VII'de aynı isimle sunulmuş olan bildirinin genişletilmiş hâlidir.

*Dr. Arşiv Uzmanı, Deniz Müzesi, İstanbul, Türkiye

ORCID: M.K. 0000-0002-7988-742X

Sorumlu yazar/Corresponding author: Mehmet Korkmaz

Deniz Müzesi, İstanbul, Türkiye

E-posta/E-mail: mkorkmaz10@gmail.com

Başvuru/Submitted: 08.03 .2020

Revizyon Talebi/Revision Requested:

06.09.2020

Son Revizyon/Last Revision Received:

11.09.2020

Kabul/Accepted: 12.09 .2020

\section{Atıf/Citation:}

Korkmaz, Mehmet. “Osmanlı Askerî Eğitiminde Modernleşme Çabaları: Kasımpaşa Bahriye Askerî Rüşdiye Mektebi" Tarih Dergisi - Turkish Journal of History, 72 (2020): 115-137. https://doi.org/10.26650/iutd.700514
ÖZ

Osmanlı Devleti, XIX. yüzyılda siyasî ve ekonomik sorunlarla uğraşırken, başta askerî olmak üzere idarî ve iktisadî birçok sahada reformlar başlattı. Askerî reformlar içerisinde ordunun ıslahı için Batı tarzı askerî eğitim modeli örnek alınarak modern okullar açıldı. Kara ve deniz harp okullarına nitelikli öğrenci bulmak amacıyla 1845 yılından itibaren askerî idadiler, 1875 yılından itibaren ise askerî rüşdiyeler açıldı. Bu uygulama askerî eğitimde kalitenin yükselmesine etki eden önemli bir faktör oldu. İlk açılan askerî rüşdiyeler arasında yer alan Kasımpaşa Askerî Rüşdiyesi'nin Türk eğitim tarihindeki yeri ve öneminin ortaya çıkarılması bu makalenin temel hedeflerinden biridir.

Anahtar sözcükler: Kasımpaşa Bahriye Askerî Rüşdiye Mektebi, Osmanlı Devleti, Eğitim, Askerî Okullar

\section{ABSTRACT}

While the Ottoman Empire was dealing with political and economic problems in the 19th century, it initiated reforms in many administrative and economic fields, including the military. Modern schools were opened by taking military training in the West as an example for the reformation of the army. Turkish military high schools began to open from 1845 in order to prepare qualified students for the Turkish Military Academy and naval academies. For the same purpose, military secondary schools were opened in 1875 . This practice was an important step to increase the quality in military education. One of the main objectives of this article is to reveal the importance of Kasımpaşa Military Secondary School, which was one of the first military secondary schools opened in the history of Turkish education.

Keywords: Kasımpaşa Naval Secondary School, Ottoman Empire, Education, Military Schools 


\section{Extended Abstract}

While the Ottoman Empire was dealing with political and economic problems in the 19th century, it initiated reforms in many administrative and economic fields as well as in the military. Modern schools were opened by taking military training in the West as an example for the reformation of the army. Turkish military high schools have been opened since 1845 in order to send qualified students to Turkish Military and Naval academies. For the same purpose, military secondary schools were opened in 1875 and began to affect the increase in the quality of military education. In this context, the main objective of this article is to reveal the importance of Kasımpaşa Military Secondary School, which was one of the first military secondary schools in the history of Turkish education.

The 19th century, which is described as the age of education for Europe, was an era in terms of having same the aspects in this field for the Ottoman Empire. Ottoman administrators, who saw that the failures, lack of weapons and equipment on the battlefields could be compensated with the qualified manpower to be trained in this field, decided to open modern military schools. Since 1875 , the opening of military secondary schools has made important contributions to the modernization of military education. Kasımpaşa Naval Military Secondary School (Kasımpaşa Askerî Rüşdiyesi) was opened in the same year. It was among the military institutions providing modern vocational training in Istanbul. In this school, an average of 250-400 students were trained per year. English was compulsory here as a foreign language. Students were trained at this school in a military discipline. Kasımpaşa was known as the neighborhood of mariner families. These people generally preferred this school for the education of their children. Thus, some families became a part of the navy with the tradition of being a sailor from father to son.

Military secondary schools were first opened in Istanbul during the period of Sultan Abdülaziz (1861-1876). These schools seemed to be very useful. In the following years, and especially during the period of Sultan Abdülhamid II (1876-1909), the number of these secondary military schools was increased. In addition, military secondary schools were opened in Anatolia. The new military secondary schools also spread to the Balkan provinces especially near the locations of military high schools. At the beginning of the 20th century, the number of military secondary schools, which were opened over a wide area from the Balkans to the Arabian Peninsula, was over 20.

Kasımpaşa Military Secondary School was constructed on a plot 31 meters long, 20 meters wide, based on a 620 square meter plot consisting of two floors. It was planned that 50-60 students would graduate from this school every year and would go to the Naval Academy in Heybeliada. Nevertheless in the first years, the this goal was not achieved. Only 18-20 students were able to graduate from the school between the years of 1877-1878. Some 
of the students left school because of their lack of success and their absence. This was an unexpected situation which caused the number of students in the Naval Academy to decrease. Every year, it was possible to send an average of about 15-20 students from Kasımpaşa Naval Military Secondary School to the Naval Academy. However, it was decided that the Naval Academy would cater for more than 40 students.

It was also seen that this number increased in certain years. For example, in 1890 it reached 25 students and 30 students in 1891. Among those there were some students who had graduated from other civilian secondary schools and who had attended the Naval Academy. There were also difficulties in finding a sufficient number of students.

Different studies were also carried out to meet the student needs. In this context, the option of sending students who graduated from civil secondary schools to the Naval Academy came to the agenda. For instance, the special school directorate named Maşrık-1 Füyûzat in the Fatih district of Istanbul was chosen to send students to Naval Academy. This school was required to include maritime-related lessons in its educational programs. The Maşrık-1 Füyûzat, the application of Kasımpaşa Naval Military Secondary School curriculum, was requested. Based on this decision those who graduated from Maşrık-1 Füyuzat were allowed to attend in the Naval Academy.

The curriculum of the Kasımpaşa Military Secondary Naval School was almost the same as other military secondary schools. In other military secondary schools, the foreign language was French, while in the Kasımpaşa Naval Military Secondary School, the foreign language was English. The reason why English language was compulsory was the import of ship and marine technology from England.

A new class was opened in 1879 in the Kasımpaşa Naval Military Secondary School. The purpose of this was to take a step towards training clerks for the navy. This class was called Menşe-i Küttab. The training period in this class was two years. Students who graduated from Naval Secondary School but who were over the age of entering the Naval Academy were selected for this training. The number of students in this system changed over the years. It was between 5 and 20 people on average. For example, 11 students graduated from this class in 1892.

With all these features, Kasımpaşa Naval Military Secondary School has an important place in the history of Turkish military education. This school was the first and only school among the military secondary schools to offer a naval education. The building of the Naval Military Secondary School continues to raise new students as an educational institution affiliated with the Turkish Ministry of National Education. 


\section{Giriș}

Türk eğitim tarihine genel hatlarıyla bakıldığında, Karahanlılar'ın 9. yüzyılın ikinci yarısından itibaren başlayan girişimlerinden Osmanlılar'ın 18. yüzyılın sonuna kadar devam eden süreç, özellikle Mühendishane-i Berrî-i Hümayun'un kurulduğu 1795'e kadar geçen uzun dönem, eğitimde klasik dönem olarak adlandırılmaktadır . Türk eğitim tarihinde bir dönüm noktası oluşturan deniz ve kara mühendishanelerinin açılması eğitimde yeni bir modern dönemin başlangıcı olmuştur. Aynı süreçte medreselerdeki eğitim faaliyeti de devam etmiştir.

Osmanlılar' da erken modern bilim ve teknik eğitimi, Humbaracı Ahmed Paşa tarafından 1734 'te yeniden düzenlenerek açılan Humbaracı Ocağı ile başlatılabilir. 18. yüzyılın ikinci yarısından sonra Osmanlılar'ın usta-çırak ilişkisi çerçevesinde sürdürülen eğitim anlayışı ile sanayi devrimini gerçekleştiren Avrupalılar'ın ulaştığı seviye arasında kapatılması güç farklılaşma meydana gelmiştir. Bu fark savaşlar sırasında kullanılan silah, teçhizat ve donanımda kendini açık şekilde göstermiştir. 1770 yılında Çeşme Faciası'nda Rus donanmasının Osmanlı donanmasını yakması sonrasında teknik donanıma sahip eğitimli kadroların yetiştirilmesi ve bir deniz mühendishanesinin açılması acil ihtiyaç olarak Osmanlı idarecilerinin karşısına çıkmıştır². Bu ihtiyacı karşılamak üzere askerî eğitimin modernleşme sürecinde önemli bir yeri olan ve donanma için hendese bilen zâbit yetiştirmek amaciyla Bahriye Mühendishanesi 1775 'te İstanbul'da açılmıştır³.

Modern eğitim anlayışı uygulamalarının devamı olarak Mühendishane-i Berrî-i Hümayun (Kara Mühendishanesi) 1795 'te ${ }^{4}$, kara ve deniz askerî birliklerinin sağlık personeli (tabip, eczacı, cerrah) ihtiyacını da karşılayacak olan Tıbbiye Mektebi 1827'de , Harbiye Mektebi $1835^{\prime}$ te $^{6}$, daha sonraki ad1 1872 y1lında Kuleli Askerî İdadisi olan Dersaadet Askerî İdadisi

1 Seyfi Kenan, "Türk Eğitim Düşüncesi ve Deneyiminin Dönüm Noktaları Üzerine Bir Çözümleme”, Osmanll Araştırmalart, say1 41 (2013), s. 1.

2 Kenan, a.g.m., s. 10-11.

3 Mühendishane-i Bahrî-i Hümayun'a ilișkin ayrıntılı bilgi için bkz. Mustafa Kaçar, Osmanlı Devleti'nde Bilim ve Eğitim Anlayışındaki Değişmeler ve Mühendishânelerin Kuruluşu, İ.Ü. Sosyal Bilimler Enstitüsü Basılmamış Doktora Tezi, 1994, s. 61-92, 111-119; İstanbul Teknik Üniversitesi ve Mühendislik Tarihimiz, ed. Mehmet Karaca, haz. Mustafa Kaçar, Tuncay Zorlu, Burak Barutçu, Atilla Bir, C. O. Ceyhan, Aras Neftçi, İTÜ Vakfi Yayınları, İstanbul 2013, s. 67-115.

4 Mühendishane-i Berrî-i Hümayun'un tarihçesi ve faaliyetlerine ilişkin bkz. Mustafa Kaçar, a.g.t., s. 92-110, 119-144; Mehmed Esad, Mir 'ât-ı Mühendishâne-i Berrî-i Hümâyûn, Karabet Matbaası, İstanbul 1312, s. 5-394; Kemal Beydilli, Türk Bilim ve Matbaacılık Tarihinde Mühendishâne: Mühendishâne Matbaası ve Kütüphânesi (1776-1826), Eren Yayıncılık, İstanbul 1995, s. 23-454; İstanbul Teknik Üniversitesi ve Mühendislik Tarihimiz, s. 115-291.

5 Tıbbiye Mektebi'nin tarihçesi için bkz. Rıza Tahsin, Tıp Fakültesi Tarihçesi (Mir'ât-ı Mekteb-i Tıbbiye), c. I-II, eklerle yay. haz. Aykut Kazancıgil, Özel Yayınları, İstanbul 1991, s. 3-153.

6 Harbiye Mektebi'nin açılışı ve faaliyetlerine ilişkin bkz. Mehmed Esad, Mir'ât-l Mekteb-i Harbiye, Artin Asaduryan Şirket-i Mürettibiyye Matbaası, İstanbul 1310, s. 8-223. 
1845 'te 7 , Bahriye İdadi Mektebi ise 1852 ' de ${ }^{8}$ faaliyete geçirilmiştir. Askerî idadiler; Harbiye, Bahriye, Mühendishane ve hatta Tıbbiye mekteplerine iyi eğitim almış öğrenci yetiştirmek amacıyla kurulmuşlardı. Ayrıca her idadide açılan iki ihtiyat sınıfından başka Mahrec-i Mekâtib-i Askeriye adı altında askerî idadilere talebe yetiştirecek bir mektep daha açılmıştı. Fakat mevcudu 500'ü geçmeyen bu mektep askerî idadiler için ihtiyaç duyulan talebeyi verememiştir'. Önce İstanbul'da açılan ve sonraki yıllarda İmparatorluğun farklı yerlerinde de tesis edilecek olan modern askerî okullar, sivil (mülki) eğitimin modernleşmesine de öncülük edeceklerdir.

19. yüzyıl Avrupa için "Eğitim Çağı" olarak nitelendirilir" ${ }^{10}$. Aynı yüzyılda Osmanlıların yukarıda açıklanan askerî eğitim sahasında attığı adımlar ve ardından eğitim reformu olarak nitelendirilebilecek diğer bazı yeni gelişmeler söz konusu olmuştur. Bu durum göstermektedir ki, 19. yüzyıl sadece Avrupa için değil aynı zamanda Osmanlılar için de bir eğitim çağı olmuştur. Osmanlıların bu çağa ayak uydurabilmek için kendi dünyası ve dinamikleri çevresinde eğitim alanındaki teşebbüsleri ve uygulamaları bu düşünceyi desteklemektedir.

Diğer taraftan 1846 yılından itibaren açılmaya başlanan genel (mülkiye) rüşdiyeler de eğitim reformunun bir diğer ayağını oluşturmuştur ${ }^{11}$. Rüşdiyeler, 1869 Maarif-i Umumiye Nizamnamesi'ne kadar ortaöğretimin ilk kademesini oluşturuyorlardı. Buralardan mezun olanlar genellikle devlet dairelerine memur olarak giriyorlardı. Önceleri sadece erkek öğrenciler için açılmakla beraber 1859 yılından itibaren kız öğrenciler için de rüşdiyeler açılmıştır. $\mathrm{Bu}$ durum, rüşdiyelerin eğitim sistemi içerisinde en kalabalık kademeyi oluşturmasıyla sonuçlanmıştır ${ }^{12}$. İbtidai okulların ve ortaöğretim kurumu niteliğindeki idadilerin 1880'lerden itibaren yaygınlık kazanmasına dek, imparatorluktaki başlıca modern devlet okulları rüşdiyelerdi. Cami imamlarının hocalık yaptığı mahalle/sıbyan mektebinden mezun olanlar

7 İstanbul Maçka'da açılan Dersaadet Askerî İdadi'si 1872 yılına kadar burada eğitim faaliyetini sürdürmüş, bu tarihten itibaren Çengelköy’deki Süvari Kışlası’na taşınarak bundan böyle eğitimini Kuleli Askerî İdadisi adıyla sürdürmüştür. Ayrıntılı bilgi için bkz. Zekeriya Türkmen, "Sultan Abdülaziz Döneminde Süvari Kışlasından Askerî İdadiye Dönüşüm Sürecinde Kuleli”, XVII. Türk Tarih Kongresi Bildirileri, 15-17 Eylül 2014, Ankara, c. IV/1. Kısım, TTK Yay., Ankara 2018, s. 79-104.

8 Bahriye Askerî İdadisi açılışı ve faaliyetleri için bkz. Fevzi Kurtoğlu, Deniz Mektepleri Tarihçesi, İstanbul Deniz Matbaası, İstanbul 1941, s. 1-28; Fahri Çoker, Bahriye Mektebimiz, DZKK. Yayınları, Ankara 1973, s.

I-XIII; Rasim Ünlü, Deniz Lisesi Tarihçesi, yayın yeri, yayınevi ve yayın yılı yok, s. 12-14.

9 Osman Ergin, Türkiye Maarif Tarihi, c. II, Osmanbey Matbaası, İstanbul 1940, s. 418.

10 Kenan, a.g.m., s. 12.

11 Osmanlı Devleti'nde rüşdiye okulları ve bunların gelişimine ilişkin bkz. Ergin, a.g.e., s. 321-341; Yahya Akyüz, Türk Eğitim Tarihi, 5. Bask1, Türk Koleji Yayınları, İstanbul 1994, s. 143-144; Uğur Ünal, II. Meşrutiyet Öncesi Osmanlı Rüşdiyeleri (1897-1907), TTK. Yayınları, Ankara 2015, s. 1-202; Selçuk Akşin Somel, Osmanlı'da Eğitimin Modernleşmesi (1839-1908), İletişim Yayınları, 2. Baskı, İstanbul 2015 s. 35-79, 94104; Mehmet Ö. Alkan, Tanzimat'tan Cumhuriyet'e Modernleşme Sürecinde Eğitim İstatistikleri 1839-1924, c. VI, T.C. Başbakanlık Devlet İstatistik Enstitüsü Yayınları, Ankara 2000, s. 5-6, 17-111; Ayşegül Altınova, Osmanlı Modernleşmesinde Rüşdiye Mektepleri, Gazi Ünv. Sosyal Bilimler Enstitüsü, Basılmamış Doktora Tezi, Ankara 2010, s. 23-428.

12 Ünal, a.g.e., s. 199. 
eğitimlerine rüşdiyelerde devam ederlerdi. Mahalle mekteplerine alternatif olarak 1872'den itibaren ilköğretim okulu olarak açılmaya başlanan ibtidailer bu eğilimi değiştirmemiş, birçok öğrenci mahalle mektebinden sonra doğrudan rüşdiyeye devam etmiştir ${ }^{13}$.

Rüşdiye mektebinden sonra öğrenciler tercihlerine göre Mülkiye, Harbiye, Mühendishane, Tıbbiye ve Bahriye mekteplerinden birine kayıt yaptırdıklarında bu okulların önce idadi kısmında eğitim görürlerdi. İmtihanlarda başarılı olduktan sonra bu mekteplerin âlî (yüksek) kısmına geçmeye hak kazanırlardı. 1864 yılında yeni bir uygulama gereği Harbiye, Mühendishane, Tıbbiye ve Bahriye mektepleri de dâhil olmak üzere bütün askerî mekteplerin idadi sınıflarındaki öğrenciler daha faydalı olacağı değerlendirilerek Galatasaray Kışlası'nda açılan Mekteb-i İdadi-i Umumiye'ye nakledildiler ${ }^{14}$. Bu uygulamanın fayda sağlamadığ 1 görüldüğünden beş yıl sonra vazgeçildi ve her mektebin idadi öğrencileri kendi okullarına gönderildi ${ }^{15}$. Müşterek askerî lise uygulaması olarak nitelendirilebilecek bu eğitimden beklenen fayda sağlanamamıştı. Bilhassa Bahriye Mektebi’ne verilecek talebelerin iyi yetiştirilmesi mümkün olmadı. Çünkü bahriye öğrencisinin idadi tahsilinde yalnızca teorik bilgi alması yeterli değildi. Denizde uygulamalı eğitim görmeleri ve denizcilik aletlerini tanımaları da icap ediyordu.

Yukarıda bahsi geçen uygulamanın doğru olmadığg Bahriye Nezareti tarafından da dile getirilmiştir. Öğrencilerin Galatasaray’da denizciliğe ilişkin uygulamalı bilgileri almaları mümkün olmadığı gibi okulda İngilizce dersi de mevcut değildi. Oysa Bahriye Mektebi'nin idadi kısmında bunlar eskiden beri mevcuttu. Avrupalı denizci devletlerdeki öğrencilerin çok erken yaşlarda yetiştirildiği mütalaasında bulunan Bahriye Meclisi, bahriye idadi öğrencilerinin Mekteb-i İdadi-i Umumiye'ye gönderilmeleri yerine bunların Heybeliada'daki Bahriye Mektebi bünyesinde açılacak olan Bahriye İdadi Mektebi’ne nakledilmelerini önermiştir ${ }^{16}$.

Bütün mekteplerin idadi sınıfları Galatasaray'da İdadi-i Umumi adı altında birleştirildiği zaman Mühendis Mektebi'nde idadi talebesinden boşalan yere bu idadilerin ihtiyat sınıfları nakledilerek orada Mahrec-i Mekâtib-i Askerîye adında orta dereceli umumi bir rüşdiye açılmıştı. Mühendishane-i Bahrî-i Hümayun ve Mühendishane-i Berrî-i Hümayun ile Mekteb-i Harbiye ve Mekteb-i Tıbbiye'nin idadi sınıflarına öğrenci hazırlamak maksadıyla açılan bu mektep, dört sınıflı olup burada yetişen öğrenciler adı geçen okullardan herhangi

13 Somel, a.g.e., s. 322, 334.

14 Galatasaray’da bütün askerî okulların idadi kısımları eğitim gördükleri sırada 16 Eylül 1865 'te öğrenciler Harbiye Mektebi'nde içtima ettirildi. Harbiye Mektebi öğrencileri önde, idadi öğrencileri arkada resmigeçit yaparak Galatasaray Kışlası'na geldiler. Kaptan-ı Derya Halil Paşa, askerî mekteplerin kumandanları ve mekteplerin amirleri resmi elbiseleriyle törende hazır bulundular. Törene Sadrazam Fuat Paşa da katılarak bir nutuk irat etti. Bkz. Ruznâme-i Ceride-i Havâdis, sayı 245, 29 Rebiülahir 1282 (20 Eylül 1865), s. 1.

15 Ergin, a.g.e., s. 400.

16 DTA, ŞUB.d, 16/32. 13 Haziran 1878. 
birinin idadi sınıflarına kayıt yaptırabilecekti. 1875 yılında askerî rüşdiyelerin açılmasıyla bu okul lağvedildi ${ }^{17}$.

Askerî eğitimin modernleştirmesine yönelik çabalar kapsamında 1875 yılında askerî idadilere nitelikli öğrenci yetiştirmek maksadıyla askerî rüşdiyeler açılmaya başlandı. İlk etapta İstanbul'da dokuz askerî rüşdiye binası inşa edildi. Askerî rüşdiyeler açılmadan evvel askerî idadi mekteplerinde dört sınıftan başka ihtiyat birinci ve ikinci seneleri adıyla iki sınıf vardı. Bu sınıflar idadi birinci sınıfa hazırlık olarak ve leylî (yatılı) tarzda tertip edilmişti. Fakat bu eğitimden verim alınamamıştı ${ }^{18} .1875$ yılında İstanbul'da açılanlar askerî rüşdiyeler ve bunların 1892 yılına gelindiğinde mevcut öğrenci sayısı şöyleydi: Gülhane (401), Soğukçeşme (530), Kocamustafaşa (392), Fatih (502), Eyüp (225), Beşiktaş (443), Üsküdar Paşakapısı (240), Üsküdar Toptaşı (250). 1884 yılında açılan Eyüp Baytar Askerî Rüşdiyesi'nde ise 432 öğrenci vard ${ }^{19}$.

Sultan Abdülaziz döneminde (1861-1876) İstanbul'da açılmaya başlanan bu rüşdiyelerden gereken fayda sağlandığı görüldüğünden Sultan II. Abdülhamid döneminde (18761909) sayıları artırıldı. Bilhassa askerî idadilerin ve ordu merkezlerinin bulunduğu bazı vilayetlerde yeni askerî rüşdiyeler açıldı. XX. yüzyıl başlarına gelindiğinde Balkanlardan Arap yarımadasına kadar uzanan geniş bir coğrafyada açılan askerî rüşdiyelerin sayısı 20'nin üzerindeydi ${ }^{20}$.

İstanbul'da ilk açılan dokuz askerî rüşdiyeden biri olan Kasımpaşa Askerî Rüşdiyesi, bu makalenin esas konusu olup, mektebin tarihçesi, müfredatı, eğitimde karşılaşılan sorunlar, mektebin Türk eğitim tarihindeki yeri ve önemi ağırlıklı olarak arşiv belgeleri ışığında ele alınmıştır. Nitekim Başkanlık Osmanlı Arşivi (BOA) ve Bahriye Nezareti evrakının muhafaza edildiği Deniz Müzesi bünyesindeki Deniz Tarihi Arşivi’ndeki (DTA) ${ }^{21}$ vesikalar ile Maarif ve Bahriye salnâmeleri bu makalenin temel kaynakları arasında yer almıştır.

17 Ergin, s. 400. Okulun programında değişik seviyelerde Osmanlı Türkçesi, Arapça ve Fransızca grameri, mantık, hesap, hendese, coğrafya ve tabiat bilgisi derslerine yer verilmiştir. Bkz. Mehmet İpşirli, "Mahreç", DIA, c. XXVII, İstanbul 2003, s. 388.

18 Mehmed Esad, Mir'at-l Mekteb-i Harbiye, s. 176.

19 Mehmed Esad, Mir'at-ı Mekteb-i Harbiye, s. 177.

20 İstanbul dışındaki askerî rüşdiyelere dair bkz. Mehmed Esad, s. 179-180; Ünal, s. 91-93; Bu rüşdiyelerdeki öğrenci ve eğitimci sayıları ile rüşdiyelerin açılış tarihine ilişkin bkz. Hülya Yarar, Osmanlı Döneminde Askerî Okullarda Ĕgitim, Milli Savunma Bakanlığı Yayınları, TTK Basımevi, Ankara 2000, s. 22-169. Askerî rüşdiyelerle ilgili yapılan son çalışmalardan biri için ayrıca bkz. Emrah Berkant Patoğlu, Osmanlı Devleti'nde Askerî Rüştiyeler, Gaziantep Üniversitesi Sosyal Bilimler Enstitüsü, Basılmamış Doktora Tezi, Gaziantep 2018, s. 41-398.

21 Deniz Tarihi Arşivi'nin tarihçesi, muhtevası ve önemine ilişkin bkz. Mehmet Korkmaz, "Yakınçağ Tarih Araştırmalarında Deniz Tarihi (Bahriye) Arşivi'nin Önemi”, 2. Uluslararası Osmanlı Coğrafyası Arşiv Kongresi, Bildiriler, c. II, T.C. Çevre ve Şehircilik Bakanlığı Tapu ve Kadastro Genel Müdürlüğ̈ Yayınları, Ankara 2019, s. 751-769. 


\section{Kasımpaşa Bahriye Askerî Rüşdiyesi}

Osmanlı Devleti'nde bahriyelilerin semti olarak bilinen Kasımpaşa'da bir bahriye askerî rüşdiye mektebi açılmasının gündeme gelmesi mülkiye rüşdiyelerinin tesisinden dört yıl sonraya, yani 1850 yılına rastlamaktadır. Bahriye Mektebi’ndeki eğitim kalitesinin yükseltilmesi maksadıyla bahriye ümera, zâbitan ve askerlerinin gerek muvazzaf gerekse emeklilerinin ekserisinin Kasımpaşa'da ikamet ettiğine vurgu yapılan Kaptanpaşalık makamından çıkan bir yazıda, öncelikle bunların çocuklarının bahriyeye kazandırılması istenmiştir. Bu amaçla Kasımpaşa' da bir bahriye askerî rüşdiye mektebi açılması ve buradan yetişecek öğrencilerin daha sonra imtihanla Bahriye Mektebi’ne gönderilmelerinin faydalı olacağına dikkat çekilmiştir ${ }^{22}$. Mektep için yeni bir bina inşası zaman alacağından mevcut okullardan birinin kullanılması önerilmiş ve Piyalepaşa Mektebi’nin rüşdiye mektebi için uygun olduğu bildirilmiştir ${ }^{23}$. Fakat mektep açılmasına ilişkin bir faaliyet o dönemde söz konusu olmamış, bir öneri halinde kalmıştır.

1875 yılına gelindiğinde Bahriye Mektebi’ndeki eğitim seviyesinin yükseltilmesi amacıyla mektepteki komisyonca hazırlanan bir raporda bahriye rüşdiye mektebi açılmasının faydalı olacağı üzerinde durulmuştur ${ }^{24}$. Bahriye Mektebi’ndeki iki yıllık eğitimin üç yıla çıkarılması, üçüncü senenin sonunda öğrencilerin Harbiye Mektebi talebesi gibi mülâzım-1 sâni (teğmen) nasp edilerek eskiden olduğu gibi iki sene talim gemisiyle gezdirilmeleri de önerilmişti. $\mathrm{Bu}$ sürenin sonunda öğrenciler mülâzım-1 evvel (üsteğmen) rütbesiyle Donanma-yı Hümayun gemilerine tayin edileceklerdi. Bu hususların icrasına ilişkin gerekli makamlardan onay alınmış ve Bahriye Mektebi'ne alınacak öğrencilerin askerî rüşdiye mektebi mezunlarından seçilmesi usulü kabul edilmişti. Böylece Harbiye Nezareti’nin açmış olduğu askerî rüşdiye mektepleri gibi Tersâne-i Âmire tarafından da bir askerî rüşdiye mektebi açılacaktı ${ }^{25}$. Alınan karar gereği Kasımpaşa'da, inşaatının sorumluluğu Tersâne-i Âmire idaresine ait olmak üzere bir askerî rüşdiye mektebinin yapımına 1875 yılının Temmuz ayında başlandı ${ }^{26}$. Üç ay gibi bir sürede mektebin kaba inşaatı tamamlandı ${ }^{27}$.

22 DTA, MKT, 11/3. Kaptanpaşalık Makamından Babıâli’ye, 14 Haziran 1850.

23 Aynı vesika; BOA, A.AMD, 28/51. 12 Ocak 1851.

24 Bahriyedeki eğitim meselesiyle ilgili ayrıntılı konulara yer veren rapor için bkz. Ergin, a.g.e., s. 364-367.

25 DTA, MKT, 241/33. Bahriye Nezareti'nden Bâbıâli'ye, 22 Nisan 1875.

26 DTA, MUH, 664/30, 4 Ağustos 1875. Mektebin inşası Yorgi Kalfa’ya ihale edildi. Mektebin inşa masrafi olmak üzere 245.430 kuruşun her taksiti 35.061 kuruş 17 para olarak, 7 taksit ile ödenmesi konusunda kendisiyle kontrat yapıldı. Paranın bahriye debboyundan tesviyesi kararlaştırılmış ve döşeme, çatı, sıva ve tamamen teslimi sonrası taksitlerinin ödeme planı 3 Temmuz 1875'te Bahriye Meclisi'nde onaylanmıştır. Mektebin kerestesi de Tersâne-i Âmire'den verilmiştir (DTA, MUH, 664/44. 24 Ekim 1875). İnşası tamamlanan mektebin kontratosu haricinde kalan kısımlarından; muhafaza duvarları, parmaklıklar, abdesthane, kömürlük ve mutfak binalarının ihalesi ayrıca yapıldı. Bunların inşası Tersâne-i Âmire kalfası Vasil Efendi’ye ihale edilmişti (DTA, MB.d, 115/59, 9 Nisan 1876). 1876 yılının Mayıs ayında mektebin kömürlük, abdesthane ve mutfak kısımlarının inşası devam ediyordu (DTA, MUH, 670/5. 9 Mayıs 1876). Bahriye Nezareti'nin bir başka kaydında mektebin inşa masraflarının 282.136 kuruş 32 para olduğu ifadesine rastlanmaktadır. Bkz. DTA, ŞUB.d, 24/97. 15 Ekim 1878.

27 DTA, MUH, 664/44. 24 Ekim 1875. 
Kasımpaşa Rüşdiye Askerî Mektebi, 31 metre uzunluğunda, 20 metre genişliğinde, 620 metrekare arsa üzerinde iki kattan ibaret bir bina olarak inşa edildi. Bahçesiyle beraber bin küsur metrekarelik bir alana sahipti. Binanın üst katında 105'er metrekare iki dershane, bir namazgâh, dört oda, 28 metre uzunluğunda ve 3,5 metre genişliğinde uzun bir koridor mevcuttu. Alt katta aynı ebatta iki dershane, bir teneffüs odas1, bir yemekhane, iki oda, kademhane ve bir salon bulunuyordu. Mektebin bahçesinde ise üç dükkân, altı kademhane ve iki şadırvan mevcuttu² ${ }^{28}$.

İnşası tamamlanan mektebe hemen öğrenci kayıt kabul işlemleri gerçekleştirilerek eğitime başlandı. Fakat rüşdiyeden mezun edilerek Bahriye Mektebi’ne gönderilmesi gereken 50-60 öğrenci ilk yıllarda gönderilemedi. Rüşdiye, 1877-1878 yıllarında ancak 18-20 öğrenci mezun edebildi. Rüşdiyeye kaydedilen öğrencilerden kimi başarısız veya devamsız olduğundan okulu terk etmiş kimi de bir üst sınıfa geçememişti. Rüşdiyeden mezun olup da Bahriye Mektebi'ne gönderilenlerin bazılarının eğitim seviyesinin düşük olduğu da görüldü29 $\mathrm{Bu}$ durum Bahriye Mektebi'nin mevcudunun azalmasına sebep oldu. Mektebin eğitim düzeyinin üst seviyelere çıkarılmasına fazla bir fayda sağlamadı. Kasımpaşa Askerî Rüşdiye Mektebi, Tersâne-i Âmire tarafından inşa edilmekle birlikte Harbiye Nezareti'nin emrine verilmişti. Mektebin Bahriye Nezareti yerine Harbiye Nezareti'nin idaresine verilmiş olması da ayrı bir sorundu. Nihayetinde Bahriye Meclisi, Kasımpaşa Askerî Rüşdiye Mektebi’nin Tersâne-i Âmire'nin idaresine verilmesi ve her sene Bahriye Mektebi için gerekli olan 50-60 öğrencinin rüşdiyeden alınması hususunda karar aldı. Rüşdiye mektebinin doğrudan doğruya Bahriye Nezareti'nin idaresine verilmesi de Bâbıâli tarafından onaylandi ${ }^{30} .1879$ yılı başlarında Kasımpaşa Bahriye Askerî Rüşdiye Mektebi adın1 ${ }^{31}$ alan okuldan mezun olup da Harbiye Mektebi'ne gitmek isteyenler olursa onlara da izin verilecekti ${ }^{32}$.

Kasımpaşa'daki Askerî Rüşdiye Mektebi'nin Bahriye Nezareti'ne devriyle buraya Tersâne-i Âmire'den ve Bahriye Mektebi'nden bahriye kökenli hocalar atandı. Fakat ilk yıllarda mektebe yeterli sayıda öğrenci bulmakta zorluk yaşandı. Mektep Müdürü olan

28 DTA, BN, 180/4050. Bahriye Rüşdiye Mektebi Müdürü Ahmed Nazif’ten Bahriye Nezaretine, 15 Eylül 1907. Günümüzde Milli Eğitim Bakanlığı’na bağlı Kadımehmet İlköğretim Okulu olarak hizmet veren okul binası, Kadımehmet Mahallesi’nde, Bahriye Hastanesi'nin arka sokağında yer almaktadır. Okul binası 1982 yılında büyük bir onarıma alınmış ve iki yıl sonra eğitime devam edilmiştir. Onarım sonucunda dış duvarlar, içeriden betonarme olarak yeniden inşa edilmiştir. Yapının plan düzeni Fatih ve Kocamustafapaşa askerî rüşdiyeleri planlarıyla büyük ölçüde benzerlik göstermektedir. İki katlı simetrik ve rasyonel formlu olan Kasımpaşa Askerî Rüşdiye binasının boyalı tüm cepheleri neoklasik özellik göstermektedir. Esma İgüs, II. Abdülhamid Dönemi Eğitim Sistemi, Eğitim Yapılarl ve Askerî Rüşdiyeler, Mimar Sinan Güzel Sanatlar Üniversitesi, Fen Bilimleri Enstitüsü Mimarlık Tarihi ve Kuramı Doktora Programı, Basılmamış Doktora Tezi, İstanbul 2008, s. 159-160.

29 DTA, ŞUB.d, 16/32. 13 Haziran 1878.

30 DTA, ŞUB.d, 16/32. 13 Haziran 1878.

31 Arşiv vesikalarında mektebin ismi birkaç farklı şekilde geçmektedir. Mekteb-i Rüşdiye-i Bahriye-i Askerî, Kasımpaşa Askerî Rüşdiyesi, Mekteb-i Rüşdiye-i Bahriye bu isimlendirmeler arasındadır. Mektebin ana giriş kapısındaki kitâbede ise Mekteb-i Rüşdiye-i Asâkir-i Bahriye ibaresi görülmektedir.

32 DTA, MB.d, 115/105. 26 Aralık 1878. 
Bahriye Kaymakamı Eyüp Sabri Bey ${ }^{33}$, Kasımpaşa civarında henüz ibtidai bir mektep açılmadığından ve sıbyan mekteplerinin de rüşdiyeye hazırlayacak tarzda bir eğitim vermediklerinden, mektebe yeterli sayıda öğrenci bulunamadığını bildirdi. Bunun birkaç sene daha devam etmesi hâlinde Bahriye Rüşdiyesi sınıflarının tamamen öğrencisiz kalacağına dikkat çekti. Bahriye Rüşdiye Mektebi'nde iki kısımdan ibaret bir sınıf açılmasını teklif eden Eyüp Sabri Bey, açılacak ilk sınıfta bir sene ibtidai mektebi derslerinin okutulmasını, buradaki eğitimlerini tamamlayanların rüşdiyenin birinci sınıfına kaydedilmelerini önerdi. Açılacak diğer bir sınıfta ise Bahriye Mektebi'nin idadi birinci sınıfında okutulan derslerin de verilmesiyle mezun edilen bu öğrenciler doğrudan Bahriye Mektebi'ne alınacaktı. Bu teklif, yani Bahriye Rüşdiye Mektebi’nde iki kısımdan ibaret olmak üzere bir ibtidai sınıfın teşkilinin faydalı olacağı Bahriye Nezareti tarafından da uygun görüldü3 ${ }^{34}$.

Heybeliada'daki Bahriye Mektebi sınıflarının 40 öğrenciden az olmaması kararı alınmasına rağmen Kasımpaşa'daki Bahriye Rüşdiyesi'nden her sene ortalama ancak 1520 kadar öğrenci Bahriye Mektebi'nin İdadi birinci sınıflarına kaydedilebildi. 1890 yılında bu sayı 25, 1891'de ise 30 öğrenciye kadar çıktı. Başka mekteplerden mezun olanlardan da Bahriye Mektebi'nin idadi birinci sınıfına kayıt yaptıranlar bulunuyordu. Fakat yine de istenilen sayıya ulaşılamadı. Bahriye Mektebi’ne bağlı başka rüşdiye mektebi olmadığından mektebin idadi sınıfına öğrenci temininde sıkıntı yaşandı. Diğer taraftan Harbiye Mektebi’ne öğrenci gönderen çok sayıda askerî rüşdiye mektebi mevcuttu. Bu rüşdiyelerden Tıbbiye Mektebi ve Mühendishane-i Berrî-i Hümayun'a öğrenci dahi verilmekteydi. Bahriye Mektebi sınıflarından donanmaya zâbit yetiştirilmesi önem arz ettiğinden bu mektep için askerî rüşdiyelerden her sene 20 öğrenci gönderilmesinin uygun olacağı Bahriye Nezareti tarafından gündeme getirildi. Konu Seraskerliğe bildirildi. Gelen cevapta askerî rüşdiyelerden mezun olan öğrencilerin istedikleri okula gitme tercihleri bulunduğundan imtihan sırasında bahriye mektebini arzu edenlerin gönderileceği beyan edildi ${ }^{35}$.

33 Eyüp Sabri Bey (1832/33-1890), 8 Mart 1848'de Bahriye Mektebi'ne girdi. Oradan mezun olduktan sonra bahriyenin çeşitli kademlerinde kâtiplik görevinde bulundu. Eyüp Sabri Bey, 1874 yılında Bahriye Mektebi’nde münşeât derslerine muallim olarak devam etti. Daha sonra Bahriye Rüşdiye Mektebi'nin müdürlüğüne atandı. Aynı zamanda Bahriye Islahat Komisyonu'na aza tayin edildi. 1883'te miralay, iki yıl sonra da mirliva rütbelerine terfi etti. 1886 yılında Bahriye Islahat ve Tetkik-i Muhasebât Komisyonu başkanlığına atandı ve vefat ettiği tarih olan 30 Eylül 1890 tarihine kadar bu görevini sürdürdü (DTA, Bahriye Nezareti Yoklama Kalemi Zâbitan Künye Defteri, 31/21). Asker olmasının yanı sıra muallim ve müverrih cephesiyle de dikkat çeken Eyüp Sabri Paşa, Haremeyn tarihi ve edebiyatı başta olmak üzere çeşitli konularda kitaplar yazan münevver bir bahriyeli olarak temayüz etti. Eyüp Sabri Paşa'nın başta Mir'âtü'l-Haremeyn (1301-1306: Bahriye Matbaası) olmak üzere altısı telif, ikisi tercüme sekiz eseri mevcuttur. Eyüp Sabri Paşa'nın Mir'atü'l-Haremeyn adlı eserinin, incelememetin olarak yapılan neşrinde, eseri yayına hazırlayanlarca giriş bölümünde paşanın diğer eserlerine ilişkin bir değerlendirme yazısı bulunmaktadır. Bkz. Eyüb Sabri Paşa, Mir'âtü'l Haremeyn Cilt 1-2. (Inceleme-Metin), haz. Ömer Fâruk Can-F. Zehra Can, Türkiye Yazma Eserler Kurumu Başkanlığı Yayınları, İstanbul 2018, s. 57-66.

34 DTA, ŞUB.d, 104/78, Şura-yı Bahriye müzekkeresi, 12 Eylül 1883.

35 DTA, ŞUB.d, 98/76. Şura-yı Bahriye'nin 19 Eylül 1883 tarihli ilâmı; DTA, MKT, 412/81. Bahriye Nezareti'nden Bahriye Mektebi'ne, 22 Aralık 1883; Ceride-i Bahriye, 1 Mayıs 1306, sayı 24, s. 37; Ceride-i Bahriye, 2 Nisan 1307, say1 49, s. 20. 
Bahriye Mektebi'ne diğer mekteplerden öğrenci gönderilmesine ilişkin çalışmalar kapsamında farklı adımlar da atıldı. Fatih semtinde bulunan Maşrık-1 Füyûzat adlı hususi mektep müdürlüğü, programına İngilizce dersi koymak ve Bahriye Rüşdiye Mektebi’nde uygulanan ders programına tatbik etmek koşuluyla mezun öğrencilerinden istekli olanların Bahriye Mektebi'ne kaydını Bahriye Nezareti'nden talep etti. Öğrencilerinin yapılacak imtihanlarında bahriye zâbitlerinden bir iki kişinin bulunmasına onay verdi. Bahriye Rüşdiye Mektebi'nden Bahriye Mektebi’ne yeterli sayıda öğrenci gönderilemediği dönemlerde adı geçen hususi mektepten öğrenci alınması Bahriye Nezareti’nce uygun görüldü. Maşrık-1 Füyûzat adlı mektebin bu girişimi Bahriye Nezareti'nin resmi yayın organı Ceride-i Bahriye'de memnuniyetle karşılanmış ve mektep idarecilerine teşekkür edilmiştir ${ }^{36}$.

Diğer taraftan Bahriye Mektebi’ne alınacak öğrencilerin Bahriye Rüşdiyesi mezunlarından alınması usulü benimsenmekle birlikte bazı bahriye zâbitlerinin çocuklarını rüşdiye mektebine göndermeksizin doğruca Bahriye idadi sınıfına kaydettirme isteklerine onay verilmedi ${ }^{37} .1884$ yılına gelindiğinde Bahriye Rüşdiye Mektebi'nde 300'ün üzerinde öğrenci eğitim görmekteydi ${ }^{38}$. Aynı yıl, Rüşdiye Mektebi Müdürü Miralay Eyüp Sabri Bey, Bahriye Islahat Komisyonundaki mesaisinin fazlalığı dolayısıyla mektepte daimi olarak bulunamadığını beyan ederek bir müdür muavini kadrosu ihdas edilmesi talebinde bulundu. Eğitim konusunda ehliyet ve liyakat sahibi olduğunu ifade ettiği Fethiye Kalyonunda görevli Binbaşı Ahmed Fahri Bey'in bu kadroya tayin edilmesine ilişkin talebi Bahriye Nezareti tarafindan uygun görüldü ${ }^{39}$.

Bahriye Rüşdiye Mektebi’ne kayıt için; sağlıklı olmak, sicilinin iyi olması, tezkere-i Osmaniyesini (nüfus cüzdanı) ibraz etmek, ailesinin zâbit veya bahriye memurlarından olması, yaşının 9-12 arasında bulunması, ibtidai mektepte Kur'an-1 Kerim, kıraat, tecvit, ilmihal, imla ve hüsn-i hat derslerini görmüş olmak gibi şartlar aranmaktayd1 ${ }^{40}$. Ailesinin zâbit veya bahriye memurlarından olmasına ilişkin maddenin, öğrencinin muhakkak bu şartı taşıması gerektiği anlamında değil, öncelikli bir tercih sebebi olarak değerlendirildiği anlaşılmaktadır. Zira okula kayıt yaptıran öğrencilerin ailelerinin farklı meslek gruplarına sahip oldukları görülmektedir.

Kasımpaşa'daki rüşdiyeden Bahriye Mektebi’ne yeterli sayıda öğrenci alınamadığı ve bunun için çareler arandığı dönemde farklı yerlerde Bahriye Mektebi açılmasına ilişkin teşebbüsler söz konusu oldu. Bartın'daki rüşdiye müdüriyetinden gelen bir teklif de bunlar arasındaydı. Bartın Rüşdiyesi Mektebi öğrencilerine dört senelik eğitim sürelerinin sonunda

36 Ceride-i Bahriye, 23 Kanun-1 sânî 1305, sayı 17, s. 4; DTA, ŞUB, 226/47. 14 Aralık 1889.

37 DTA, MKT, 360/26. Bahriye Nezareti'nden Bahriye Mektebi Nezareti'ne, 19 May1s 1881.

38 DTA, MKT, 403/13. 13 Şubat 1884.

39 DTA, ŞUB.d, 106/96. 7 Mayıs 1884 tarihli Şura-yı Bahriye ilamı.

40 DTA, BN, 180/4050. 
bahriyeye ilişkin derslerin tahsil ettirilmesi okul müdürü tarafından gündeme getirildi. Öğrencilerin okulda iki yıl daha okuyarak bu süre zarfında bahriye dersleri görmelerini, bunun için ise bahriyeden bir muallim gönderilmesini talep etti. Bahriye Nezareti bu uygulamanın faydalı olacağı yönünde görüş bildirdi. Oradaki bahriyeli liman reisinin bu dersleri verebileceği Bahriye Nezareti'nin mütalaasında yer ald ${ }^{41}$. Fakat bu tasarı uygulama safhasına geçirilmedi.

Osmanlı bahriyesinde müşavir olarak görev yapan Alman vatandaşı Starcke Paşa da donanmanın ve Bahriye Mektebi'nin ıslahına ilişkin hazırladığı bir raporunda bahriye eğitimi konusuna değinmişti. 1886 tarihli raporunun bir maddesinde, uzun sahillere sahip olan devletin farklı yerlerde bahriye mektepleri açması gerektiğini ifade etti. Paşa, Bahriye Mektebi'nin her sene verdiği mezun sayısının az olduğunu, mesela 1884 'te 10,1885 'te 21 , 1886 senesinde 10 olmak üzere üç yılda toplam 41 zâbitin donanmaya katıldığını ifade ederek bu sayının artırılması amacıyla farklı yerlerde bahriye rüşdiye mektepleri açılmasını önerdi. Trabzon, Sinop, Girit, Sakız, Midilli, İzmir, Selanik, Beyrut, Dedeağaç, Trablusgarp'ın yanı sıra Basra'da Bahriye Nezareti'ne bağlı mektepler açılmasının fayda sağlayacağı raporda beyan edilmişti ${ }^{42}$. Fakat taşrada mektep açmanın hayli masraflı olması ve o sırada devletin içinde bulunduğu mali sıkıntılar sebebiyle olsa gerek bu teklif kabul görmemiştir.

\section{Bahriye Askerî Rüşdiyesi’nin Ders Programı}

Bahriye Askerî Rüşdiyesi'nin ders programına bakıldığgnda aslında Harbiye Nezareti’ne bağlı kara askerî rüşdiyeleriyle neredeyse aynı derslerin gösterildiği görülmektedir. Hatta çok az farkla mülkiye rüşdiye mektepleri ile de aynı derslerin okutulduğunu söylemek mümkündür. Okuldaki dört yıllık eğitim süresince saat olarak müfredatta en fazla yer alan ders, 12 saat ile ilm-i hesaptır. Ayrıca 10 saat ile imlâ-yı Osmânî, 7'şer saat ile hüsn-i hat ve İngilizce derslerine de yer verilmiştir. Kara kuvvetlerine öğrenci yetiştiren askerî rüşdiyelerde yabancı dil Fransızca iken Bahriye Rüşdiyesi’nde yabancı dil İngilizce'dir. Askerî rüşdiye müdür ve muallimlerinin genellikle subay olması, öğrencilerin askerî üniforma giymeleri ve yabancı dil dersinin Fransızca/İngilizce olması askerî rüşdiyeleri diğer sivil rüşdiyelerden ayırt edici özelliği olarak gözükmektedir. Bahriye eğitiminde yabancı dil olarak İngilizce

41 DTA, ŞUB.d, 101/34. Şûrâ-y1 Bahriye Müzekkeresi, 25 Mayıs 1882; DTA, MKT, 377/80. Bahriye Nezareti'nden Maarif Nezareti'ne, 3 Haziran 1882. Diğer taraftan Karadeniz sahillerindeki bazı rüştiye mekteplerine bahriye zâbitlerinden birer muallim tayin edilerek öğrencilere ve gemi kaptanlarına kaptanlık dersleri verilmesi de aynı yıl gündeme geldi. Ayrıca Akdeniz ve Karadeniz sahillerinin kimi mevkilerinde bahriye ticaret mektepleri açılması önerildi. Bunun ticaretin gelişmesini sağlayacağı değerlendirildi. Bahriye Nezareti, denizcilik derslerinin ancak rüştiye mekteplerindeki dersler görüldükten sonra bahriyeli bir zâbit tarafından verilmesinin uygun olacağını ifade etti. Bu konuda bir nizamname kaleme alınması ve yapılacak ders programında temel denizcilik derslerinden hesap, coğrafya, hendese, cebir, münşeat, heyet-i seyrisefain gibi derslerin müfredatta bulunmasının icap edeceği beyan olundu. DTA, MKT, 380/44. Bahriye Nezaretinden Ticaret ve Ziraat Nezaretine, 25 Eylül 1882.

42 BOA, Y.PRK.ASK, 36/99. 17 Kasim 1886. 
gösterilmesi gemi ve deniz teknolojisinin İngiltere'den ithal edilmesiyle ilgili bir husus olduğu bilinmektedir ${ }^{43}$. Bahriye Askerî Rüşdiye Mektebi'nin 1894 yılı ders programı şöyleydi ${ }^{44}$.

\begin{tabular}{|c|c|c|c|}
\hline \multicolumn{4}{|c|}{ Bahriye Askerî Rüşdiye Mektebi Ders Programı (1894) } \\
\hline Birinci Sene & İkinci Sene & Üçüncü Sene & Dördüncü Sene \\
\hline $\begin{array}{l}\text { İlmihal } \\
\text { (Haftada } 3 \text { saat) }\end{array}$ & $\begin{array}{c}\text { Sarf-1 Arabî } \\
\text { (Haftada } 3 \text { saat) }\end{array}$ & $\begin{array}{c}\text { Nahv-1 Arabî } \\
\text { (Haftada } 3 \text { saat) }\end{array}$ & $\begin{array}{c}\text { Mantık ve Tatbikat-1 } \\
\text { Arabiye } \\
\text { (Haftada } 2 \text { saat) }\end{array}$ \\
\hline $\begin{array}{l}\text { Ta'lim-i Kiraat } \\
\text { (Haftada } 3 \text { saat) }\end{array}$ & $\begin{array}{l}\text { Kavâid-i Fârisî } \\
\text { (Haftada } 2 \text { saat) }\end{array}$ & $\begin{array}{c}\text { Gülistân } \\
\text { (Haftada } 1 \text { saat) }\end{array}$ & $\begin{array}{l}\text { Nahv-1 Osmânî } \\
\text { (Haftada } 2 \text { saat) }\end{array}$ \\
\hline $\begin{array}{l}\text { İmlâ-yı Osmânî } \\
\text { (Haftada } 3 \text { saat) }\end{array}$ & $\begin{array}{l}\text { İmlâ-yı Osmânî } \\
\text { (Haftada } 3 \text { saat) }\end{array}$ & $\begin{array}{l}\text { İmlâ-yı Osmânî } \\
\text { (Haftada } 2 \text { saat) }\end{array}$ & $\begin{array}{c}\text { Resim } \\
\text { (Haftada } 1 \text { saat) }\end{array}$ \\
\hline $\begin{array}{l}\text { Hüsn-i Hat } \\
\text { (Haftada } 3 \text { saat) }\end{array}$ & $\begin{array}{c}\text { Resim } \\
\text { (Haftada } 1 \text { saat) }\end{array}$ & $\begin{array}{c}\text { Resim } \\
\text { (Haftada } 1 \text { saat) }\end{array}$ & $\begin{array}{l}\text { İmlâ-yı Osmânî } \\
\text { (Haftada } 2 \text { saat) }\end{array}$ \\
\hline $\begin{array}{l}\text { İlm-i Hesap (Haftada } \\
3 \text { saat) }\end{array}$ & $\begin{array}{c}\text { Hüsn-i Hat } \\
\text { (Haftada } 2 \text { saat) }\end{array}$ & $\begin{array}{c}\text { Hüsn-i Hat } \\
\text { (Haftada } 1 \text { saat) }\end{array}$ & $\begin{array}{c}\text { İngilizce } \\
\text { (Haftada } 3 \text { saat) }\end{array}$ \\
\hline \multirow[t]{5}{*}{$\begin{array}{l}\text { Ta'lim-i Fârisî } \\
\text { (Haftada } 2 \text { saat) }\end{array}$} & $\begin{array}{c}\text { İngilizce } \\
\text { (Hafta iki saat) }\end{array}$ & $\begin{array}{c}\text { İngilizce } \\
\text { (Haftada } 2 \text { saat) }\end{array}$ & $\begin{array}{c}\text { Hüsn-i Hat } \\
\text { (Haftada } 1 \text { saat) }\end{array}$ \\
\hline & $\begin{array}{c}\text { İlm-i Hesap } \\
\text { (Haftada } 3 \text { saat) }\end{array}$ & $\begin{array}{c}\text { İlm-i hesap } \\
\text { (Haftada } 3 \text { saat) }\end{array}$ & $\begin{array}{c}\text { İlm-i hesap } \\
\text { (Haftada } 3 \text { saat) }\end{array}$ \\
\hline & $\begin{array}{c}\text { Akaid-i Diniye } \\
\text { (Haftada iki saat) }\end{array}$ & $\begin{array}{c}\text { Coğrafya } \\
\text { (Haftada } 2 \text { saat) }\end{array}$ & $\begin{array}{c}\text { Usûl-i Defterî } \\
\text { (Haftada } 1 \text { saat) }\end{array}$ \\
\hline & & $\begin{array}{c}\text { Sarf-1 Osmânî } \\
\text { (Haftada } 2 \text { saat) }\end{array}$ & $\begin{array}{c}\text { Hendese } \\
\text { (Haftada } 1 \text { saat) }\end{array}$ \\
\hline & & & $\begin{array}{l}\text { Coğrafya-yı Umûmî } \\
\text { (Haftada } 2 \text { saat) }\end{array}$ \\
\hline
\end{tabular}

Yukarıdaki tabloda gösterilen temel derslerin haricinde kısa süreli de olsa bazı derslerin müfredatta yer almasına dair çalışmalar olduğu da anlaşılmaktadır. Bahriye Mektebi idaresi tarafından 1892 yılında gündeme getirilen hüsn-i ahlak dersinin müfredatta yer almasına dair talep bunlar arasındadır. Bahriye Mektebi öğrencilerinin ahlaki yönden iyi yetişmelerini temin için onların daha mektebe gelmeden Bahriye Rüşdiye Mektebi'nde adı geçen dersi görmelerinin önemi üzerinde durulmuştur. İlgili teklif Bahriye Nezareti'nin en üst karar mercii olan Şura-yı Bahriye ve Erkân-1 Harbiye-i Bahriye Dairesi tarafından da uygun görülmüştür ${ }^{45}$.

Bahriye Rüşdiye Mektebi'nin eğitimcileri arasında önemli isimler de mevcuttu. Hammer Tarihi'ni tercüme eden kaymakam rütbesindeki Piyaleli Mehmed Ata Bey ile Yüzbaşı

43 Sivil rüşdiyelerde gösterilen derslerin programları ile bunların haftalık ders saatleri ve ders içeriklerine ilişkin ayrıntılı bilgi ve askerî rüşdiye ders programları ile karşılaştırma için bkz. Umum Mekâtib-i Rüşdiyeye Mahsus Olarak Bu Kere Ta'dilen Tertip Edilen Ders Programıdır, Matbaa-i Âmire, Dersaadet 1315, s. 3-37.

44 DTA, BN, 181/4063: "Mekteb-i Rüşdiye ve Menşe-i Küttâb-1 Asâkir-i Bahriyenin 1310 [1894] Senesine Mahsus Ders Cetveli” başlıklı vesika. 1886 yılı ders programı için ayrıca bkz. DTA, EHB.d, 9/18.

45 DTA, MKT, 685/186. Bahriye Nezareti'nden Bahriye Mektebi'ne, 1 Mart 1892. 
Mehmed Habib Efendi ${ }^{46}$ İngilizce derslerine, meşhur deniz ressamlarından Bahriye Kolağası Kumkapılı Fahri Kaptan ${ }^{47}$ ise resim derslerine girdiler. Arapça dersine Ahmed Ramiz ile Ahmed Rıfat efendiler, akaid-i diniye, Farsça, ilmihal, kıraat derslerine Âşir Efendi ${ }^{48}$, Osmanlıca dersine Kol-1 sanî Kulaksızlı Ali Rıza Efendi Kaptan ile Yüzbaşı Osman Efendi, coğrafya dersine Kol-1 sâni Üsküplü Mehmed Efendi Kaptan, hendese dersine Kol-1 sanî Kasımpaşalı Mustafa Tevfik Efendi Kaptan, muhasebe dersine Korvet Kâtibi Mehmed Yunus Efendi, ilm-i hesap dersine Hasan Efendi ve Kol-1 sani Mustafa Tevfik Efendi, usul-i defterî dersine Habib Efendi, Osmanlıca imla dersine ise Şemseddin Efendi girmişlerdir. Bahriye Rüşdiyesi Mektebi'nde 1876-1883 yılları arasında o dönem kaymakam/miralay rütbelerinde görev yapan Eyüp Sabri Bey, 1898-1908 yılları arasında ise Binbaşı Ahmed Nafiz Bey ${ }^{49}$, mektepte en uzun süre müdürlük görevinde bulunanlar arasında yer aldılar ${ }^{50} .1892$ senesinde ise Binbaşı Sami Bey mektepte müdür olarak görev yapıyordu ${ }^{51}$.

Diğer taraftan Bahriye Rüşdiyesi'nden mezun olan öğrencilerin tamamının bahriye mektebine gitmeleri gibi genel bir hüküm de yoktu. Bu rüşdiyeden mezun olduktan sonra Bahriye Merkez Hastanesi'nde gerekli eğitimi alıp cerrah olanlara ya da medrese eğitimine geçiş yapıp ilmiye sınıfına katılanlara da rastlanmaktadır. Mesela Kasımpaşalı Kadirî dergâhı şeyhi, Rıfaî dergâhı zakircibaşı ve musikişinas Cemaleddin Efendi (1871-1937), Abdülkadir Çavuş İbtidai Mektebi'nden sonra Bahriye Rüşdiyesi'ne girmiş ve buradan mezun olmuştur. Sonra Bayezıd Camisi'ndeki derslere devam ederek hafızlık ve imamlık icazeti almıştır.

46 Yüzbaşı Mehmed Habib Efendi İngilizce derslerinin daha kolay anlaşılmasını sağlamak amacıyla 1898 yılında İngilizce Usûl-i Mükâleme adlı bir eser neşretmiştit. Ceride-i Bahriye'de yer alan bir yorumda bu konuda memlekette pek az eser bulunması ve İngilizce eğitiminde çekilen zorluk göz önüne alındığında yeni neşrolunan eserin pek faydalı olacağı ifadesine yer verilmişti. Ceride-i Bahriye, sene 10, sayı 23512 Mayıs 1314 [24 Mayıs 1898].

47 Fahri Kaptan, bahriye sağ kolağası rütbesindeyken 12 Şubat 1910'da emekli olmuş ve 2 Mart 1917'de İstanbul'da vefat etmiş̧ir. Hayatı ve eserlerine ilişkin ayrıntılı bilgi için bkz. Serdar Başaran-Levent Düzcü, Osmanlı'dan Cumhuriyet'e Denizciler: Yelkenli ve Buharll Çağın Emektarları, Kriter Yayınevi, İstanbul 2016, s. 80-81.

48 Âșir Efendi, 1888 yılında Tuhfet'ül-Etfâl adlı bir eserinin bastırılması için müracaatta bulunmuş ve buna Maarif Nezareti'nce onay verilmişti: BOA, MF.MKT, 100/56, lef 1. 23 Temmuz 1888.

49 Mustafa oğlu Dırağmanlı Binbaşı Ahmed Nafiz Bey,13 Nisan 1866'da öğrenci olarak Bahriye Mektebi'ne girdi. 19 Temmuz 1873’te mülâzım-1 sânî rütbesi ile mezun oldu. Aynı yılın eylül ayında mülâzım-1 evvel, 1876 yılında yüzbaşı, 1877 yılında sol kolağası, 14 Ekim 1890 tarihinde ise Binbaşı rütbesine yükseldi. 27 Ağustos 1907'de kaymakam rütbesine terfi etti. Bu rütbedeyken 4 Ocak1910'da emekli edildi. DTA, Bahriye Nezareti Yoklama Kalemi Zâbitân Künye Defteri, 31/242; Salname-i Bahrî, Dördüncü Def'a, Matbaa-i Bahriye, Dersaadet 1311, s. 64.

50 DTA, BN, 181/4063: "Mekteb-i Rüşdiye ve Münşe-i Küttâb-1 Asâkir-i Bahriyenin 1310 Senesine Mahsus Ders Cetveli” başlıklı vesika. Ayrıca Bahriye Askerî Rüşdiye Mektebi’nde görev yapan muallimler için bkz. Salname-i Bahrî, Birinci Def'a, Matbaa-i Bahriye, Dersaadet 1307, s. 80-81; Salname-i Bahrî, İkinci Def'a, Matbaa-i Bahriye, Dersaadet 1308, s. 67; Salname-i Bahrî, Dördüncü Def'a, Matbaa-i Bahriye, Dersaadet 1311, s. 64; Bahriye Salnamesi, Ondördüncü Def'a, Matbaa-i Bahriye, Dersaadet 1321, s. 66-67.

51 Bu sırada Bahriye Mektebi'nde ders nazırı olarak görev yapan Miralay Nafiz Bey'in, Heybeliada'nın havasıyla imtizaç edemediği gerekçesiyle Bahriye Nezareti'ne başvurması üzerine Bahriye Rüşdiye Mektebi Müdürü Sami Bey ile becayiş yapması Şura-yı Bahriye tarafından uygun görülmüştü. DTA, MKT, 729/5. Bahriye Nezareti’nden Mabeyn-i Hümayun'a, 13 Ekim 1892. 
Bir diğer örnek meşhur deniz harp tarihçisi Safvet Bey'dir. Bahriye Rüşdiyesi’nden sonra Heybeliada Bahriye Mektebi'ne devam eden Safvet Bey, buradan bahriye subayı olarak mezun olmuştur. Kasımpaşalı Halid bin Mehmed Efendi ise Bahriye Rüşdiyesi'nden mezun olup farklı bir alana geçiş yapanlara diğer bir örnektir. Kasımpaşa Yahya Kethüda İbtidai Mektebi'nden sonra Bahriye Rüşdiyesi'nden mezun olan Halid Efendi, ardından Gümüşsuyu Hastanesine devam ederek buradan 1895 yılında cerrah diploması almış ve Bahriye Merkez Hastanesi'nde işe başlamıştır ${ }^{52}$.

\section{Bahriyeye Kâtip Yetiştirmek Üzere Bahriye Rüşdiyesi'nde Menşe-i Küittâb Sınıfı Açılması}

Donanma-yı Hümayun'un yazı işlerinde istihdam edilen kâtip memurlar, 1864 yılına kadar "hoca" unvanıyla isimlendirilirdi. 16 Ocak 1864 tarihinde buna ilişkin yapılan yeni bir düzenlemeyle hoca unvanı lağvedilerek bahriyede istihdam edilecek kâtipler dört sınıfa ayrıldı. Brik, korvet, firkateyn ve kalyon kâtipliği olarak adlandırılan bu sınıflardan ilki mülâzım-1 sâni (teğmen), ikincisi mülâzım-1 evvel (üsteğmen), üçüncüsü yüzbaşı ve dördüncüsü yani kalyon kâtipliği ise sol kolağası (kıdemli yüzbaşı) rütbelerine muadil tutuldu. İstihdam edilecek kâtiplerin imtihanla bölük eminlerinden seçilmesi de yeni düzenlemeyle karara bağland1 ${ }^{53}$. Bahriyede istihdam edilen kâtiplerin bu rütbelerle terfi etmeleri Osmanlı Devleti'nin son zamanlarına kadar devam etmekle birlikte bunların eğitimleriyle ilgili hususlarla bazı yeni düzenlemeler gerçekleştirildi.

Bahriyenin yazı ve muhasebe işlerinde aynı zamanda okuryazar neferler de görevlendiriliyordu. Bu neferlerden tezkere bırakıp da kâtip olarak görev almak isteyenler olursa brik kâtibi rütbesiyle bahriyeye kaydı yapılırdı. Bunlar sırasıyla korvet, firkateyn ve kalyon kitâbeti rütbelerini alarak terfi ederlerdi. Kalyon kâtibi rütbesine kadar terfi edenlerin bahriye harp sınıfına geçişleri mümkündü. 1879 yılına ait bir kayıttan anlaşıldığına göre kalyon kâtibi rütbesine gelmeden bazı kâtiplerin hususi başvuru yaparak mülâzım rütbesiyle harp sınıfına geçirildiklerinin görülmesi, Bahriye Nezareti'nin en üst karar alma organı olan Şura-yı Bahriye tarafından uygun görülmemiştir. Böyle bir uygulamanın eskiden beri devam edegelen usule aykırı olduğu değerlendirilerek gerekli hassasiyetin sorumlular tarafından gösterilmesi istenmiştir ${ }^{54}$. Aynı yıl Bahriye Nezareti ve bağlı birimleri ile bilhassa donanma gemilerinde hesap işlerinin önem kazandığ 1 göz önünde bulundurularak istihdam edilecek kâtiplerin daha iyi yetiştirilmesi gerektiği gündeme gelmiştir. Bu maksatla Bahriye Rüşdiye Mektebi'nde 7 Temmuz 1879 tarihinde eğitim süresi iki yıl olan Menşe-i Küttâb adlı hususi bir sınıf açıldı. Bahriye Rüşdiye Mektebi’nden mezun olup da yaşları Bahriye Mektebi’ne girme sınırını aşanlar bu sınıfa nakledildiler. Sınıflardaki öğrenci sayısı yıllara göre 5 ila

52 DTA, BH.SAID, 18916/135. Lef 1.

53 Ceride-i Askeriye, sayı: 1, 23 Şaban 1280 [2 Şubat 1864], s. 3.

54 DTA, ŞUB.d, 26/4. Şura-yı Bahriye'nin Re’sen Müzekkeresi, 13 Mayıs 1879. 
20 arasındaydı. Buradan ilk mezun olanların iyi yetiştirildiği de görülmüştür ${ }^{55}$. Adı geçen sınıftan 1892 yılında 11 öğrenci mezun oldu ve bunlar brik kâtibi olarak Bahriye Nezareti’nin çeşitli birimlerinde göreve başladılar ${ }^{56}$.

Menşe-i Küttâb sınıfı ilk açıldığı yıllarda gösterilen derslerin öğrencilerin kapasitelerinin üzerinde olması sebebiyle sonradan bazı değişikliklere gidildi. Kitâbet dersi hocası Korvet Kâtibi Mehmed Celaleddin Efendi, hazırladığı bir raporunda belagat-i Osmaniye, hukuk-1 bahriye ve tarih-i umumi gibi yüksek mektep öğrencilerinin bile zor anladıkları bazı derslerin Menşe-i Küttâb sınıfı ders programında bulunmasının yanlış olduğu değerlendirmesinde bulunmuştu ${ }^{57}$.

Bahriye Askerî Rüşdiyesi bünyesindeki Menşe-i Küttâb sınıfı, rüşdiye ve idadi mekteplerinin eğitim kalitesinin yükseldiği gerekçesiyle 1900 yılında kapatıldı. Kâtip olarak tekrar bahriye askerleri arasından okuma yazma bilenler ve Bahriye Rüşdiye Mektebi'nin son sınıfi talebesinden olup da Bahriye Mektebi'ne kabul edilmeyenler brik kâtibi unvanıyla bahriyede görevlendirildiler. Fakat bunlardan beklenen verim alınamadığından kâtip yetiştirilen sınıfın yeniden açılması gündeme geldi ${ }^{58}$. Açılacak sınıfın iki sene yerine dört seneye çıkarılması, mezun olanların brik kâtibi sıfatıyla bahriyede istihdamları, okutulacak derslerin idadi ve aliyye sınıfları derecesindeki derslere eşit olması kararlaştırıldı. Ayrıca Bahriye Nezareti'nce ihtiyaç duyulan hesap usullerine göre müfredatta düzenleme yapıldı. Bu sınıflara gireceklerin sayısı her sene beşten fazla olmayacaktı ${ }^{59}$. Tekrar açılan Menşe-i Küttâb sınıfında 1901 yılından itibaren okutulan dersler şöyleydi ${ }^{60}$ :

55 DTA, BN, 180/4050. Islahat ve Tetkik-i Muhasebat-1 Bahriye Komisyonu'ndan Bahriye Rüşdiye Mektebi Müdüriyetine, 21 Nisan 1904; DTA, BN, 180/4050. Islahat ve Tetkik-i Muhasebat-1 Bahriye Komisyonu'nun mütalaası, 24 Temmuz 1901; DTA, BN, 180/4050. Bahriye Rüşdiye Mektebi Müdürü Ahmed Nazif'ten Bahriye Nezareti'ne, 26 Ekim 1901.

56 Mezun olan 11 öğrencinin isim listesi için bkz. Ceride-i Bahriye, 9 Haziran 1308, say1 80, s. 59.

57 DTA, BN, 180/4050. Bahriye Nezareti Harbiye Komisyonuna Memur Korvet Kâtibi Mehmed Celaleddin Efendi'den Bahriye Nezareti'ne. 30 Eylül 1893.

58 DTA, BN, 180/4050. Islahat ve Tetkik-i Muhasebat-1 Bahriye Komisyonu'nun mütalaası. 24 Temmuz 1901.

59 DTA, aynı vesika.

60 DTA, BN, 180/4050; DTA, BN, 181/4063: "Mekteb-i Rüşdiye ve Menşe-i Küttâb-1 Asâkir-i Bahriyenin 1310 Senesine Mahsus Ders Cetveli” başlıklı vesika. 


\begin{tabular}{|l|c|c|c|}
\hline \multicolumn{4}{|c|}{ Menşe-i Küttâb Sınıfi Ders Programı (1901) } \\
\hline Birinci Sınıf & İkinci Sınıf & Üçüncü Sınıf & Dördüncü Sınıf \\
\hline Tatbikat-1 Hesabiye & Tatbikat-1 Hesabiye & Mebâdi-i Hendese & Usûl-i Hendese \\
\hline $\begin{array}{l}\text { Dersaâdet Muhasebe-i } \\
\text { Askerîyesi }\end{array}$ & Taşra Muhasebe-i Askerîyesi & $\begin{array}{c}\text { Muhasebât-1 Umumiye-i } \\
\text { Bahriye }\end{array}$ & $\begin{array}{c}\text { Muhasebât-1 Umûmiye-i } \\
\text { Bahriye }\end{array}$ \\
\hline Gülistân & Tarih-i Osmânî & Tarih-i Osmânî & Tarih-i Umûmî \\
\hline Kavâid-i Kitâbet & Kavâid-i Kitâbet & Kitâbet-i Resmiye & Kitâbet-i Resmiye \\
\hline $\begin{array}{l}\text { Telhis, Nahiv ve } \\
\text { Tatbikat-1 Arabiye }\end{array}$ & İzhar ve Tatbikat-1 Arabiye & $\begin{array}{c}\text { Mantık ve Tatbikat-1 } \\
\text { Arabiye }\end{array}$ & Belagat-i Osmâniyye \\
\hline İngilizce Gramer & İngilizce Gramer & İngilizce & İngilizce \\
\hline Coğrafya-yı Osmânî & $\begin{array}{c}\text { Kavânîn-i Bahriye ve Nizâmât-1 } \\
\text { Mevcûde }\end{array}$ & Usûl-i Defterî & $\begin{array}{c}\text { I̧şâtr-1 Umûmiye-i } \\
\text { Bahriye }\end{array}$ \\
\hline Hüsn-i Hat & Hüsn-i Hat & Hüsn-i Hat & Hüsn-i Hat \\
\hline Akaid-i Diniye & Akaid-i Diniye & Akaid-i Diniye & Akaid-i Diniye \\
\hline
\end{tabular}

Menşe-i Küttâb sınıfındaki derslere Bahriye Rüşdiye Mektebi’nde vazifeli muallimler girdi. Yeni müfredatta dersler tespit edilirken daha evvelki mezunların hesap işlerinde yaptıkları bazı yanlışlıklar dikkate alındı. Menşe-i Küttâb sınıfına, Bahriye Rüşdiye Mektebi'nin son sınıfından Bahriye Mektebi'ne kabul imtihanını verip de yaşı 16'yı aştığından dolayı mektebe kabul edilememiş olanlar alındı. Ayrıca Bahriye Rüşdiye Mektebi'ndeki dört yıllık tahsil müddeti süresince hiçbir vukuatı olmaması ve son sınıfta başarı sıralamasında ilk 16 kişi arasında bulunması gibi ölçütler Küttâb sınıfına kayıtta esas alındı ${ }^{61}$. Sınıftan her sene verilen mezun sayısı ortalama 10 kişi civarındaydı. 1890 yılında dört, 1904 yılında ise on öğrenci mezun olmuştu ${ }^{62}$. Bunlar ilk olarak teğmen rütbesine tekabül eden brik kâtibi rütbesiyle bahriyede istihdam edildiler.

1904 yılına gelindiğinde brik kâtiplerinin mevcudunun yeterli olması ve aynı zamanda bütçe tahsisatının kifayetsizliği sebebiyle küttâb sınıfı kapatıldı ${ }^{63}$. Ancak II. Meşrutiyet'in ilanından sonraki dönemde bahriye kâtiplerine ihtiyacın ortaya çıkması üzerine yeniden açılması gündeme geldi. Heybeliada' da Çarkçı Mektebi açıldığı zaman burada eğitim süresi iki yıl olan bir kâtip mektebi açıldı ${ }^{64}$.

Bahriye kâtipleri aynı zamanda levazım zâbiti idiler. Bundan dolayı sıhhi durumları güverte ve makine hizmetlerine elverişli olmayanlardan bir kısmı ordu ve levazım zâbitleriyle birlikte kâtip olarak yetiştirilmekte ve bunlar ihtiyacı karşılayamadığg takdirde ordudan yetişen levazım zâbitleriyle noksan tamamlanmaktayd ${ }^{65}$.

61 DTA, BN, 180/4050. Islahat ve Tetkik-i Muhasebat-1 Bahriye Komisyonu'nun mütalaası. 19 Aralık 1900; DTA, ŞUB.d, 498/101. 23 Şubat 1901.

62 DTA, ŞUB.d, 273/9. 15 Ağustos 1890; DTA, Islahat, 227/17. Bahriye Islahat Komisyonu Kararı.18 Mayıs 1904.

63 DTA, BN, 180/4050. Islahat ve Tetkik-i Muhasebat-1 Bahriye Komisyonu'nundan Bahriye Rüşdiye Mektebi Müdüriyetine, 21 Nisan 1904.

64 Ergin, s. 1168.

65 Ergin, s. 1168. 


\section{Bahriye Mektebi Müfredatında Yeni Düzenlemeler ve Bahriye Rüşdiye Mektebinin Kapatılması}

1907 yılının Eylül ayında Bahriye Rüşdiye Mektebi'nin Kasımpaşa'dan Azapkapı’ya taşınması gündeme geldi. Buradaki 20 öğrenci kapasiteli eski Neharî Tüccar Kapudan Mektebi'nin binası bu iş için düşünüldü. Fakat 200 öğrencisi bulunan Bahriye Rüşdiye Mektebi için binanın yetersiz geleceği görüldügüñnden bundan vazgeçildi ${ }^{66}$. Bu teşebbüsten bir y1l sonra Bahriye Mektebi’nde yapılan yeni düzenlemeler gereği Bahriye Rüşdiye Mektebi’nin kapatılması gündeme geldi. Bahriye Mektebi’nden seçkin zâbit yetiştirmek maksadıyla İngiltere ve Amerika gibi gelişmiş ülkelerdeki ders programları incelenmiş ve Bahriye Mektebi’ndeki idadi adı kaldırılmayarak mektepteki eğitim süresi altı seneye çıkarılmıştır. Öğrencilerin ilk dört yıl mektepte, son iki yıl ise seyyar talim gemisinde eğitim görmeleri usulü uygun görülmüştü. Bahriye Mektebi’ne alınacak öğrenciler idadi mezunlarından imtihanla temin edilecekti. Bu yüzden Bahriye Rüşdiye Mektebi'ne artık lüzum kalmamıştı. 20 Eylül 1908'de Bahriye Nezareti bu yeni uygulamayı onayladı ${ }^{67}$. Bahriye Rüşdiye Mektebi’nde eğitim gören öğrenciler çevredeki rüşdiye ve idadi okullarına gönderildiler. Fakat mektebin son sınıf öğrencileri bu durumun kendilerini mağdur ettiği, maksatlarının asker olarak devlete hizmet etmek olduğu ve 3-4 yıldır eğitim gördükleri halde bunun semeresini göremedikleri gerekçeleriyle Sadaret'e dilekçe verdiler. Bunun üzerine onların da Bahriye Mektebi'ne alınmaları konusunda karar çıktı ${ }^{68} .1875$ yılında açılmasından lağv edildiği tarih olan 1908 yılına kadar eğitim hayatını sürdüren Kasımpaşa'daki Bahriye Rüşdiyesi'nin lağvından beş yıl sonra Osmanlı hükûmeti bütün askerî rüşdiyeleri kapattı. Bunların binaları Maarif Nezareti’ne devredildi ${ }^{69}$.

XIX. yüzyılın sonlarına doğru Osmanlı bahriyesine nitelikli eleman yetiştirmek üzere Bahriye Nezareti'ne bağlı başka mektepler de vardı. Bunlara da kısaca değinmek bahriyedeki eğitim sisteminin daha iyi anlaşılmasına katkı sağlayacaktır. Bahriye Mektebi’ne, Menşe-i Küttâb-ı Askerî sınıfına ve Çarkçı Ameliyat Mektebi’ne öğrenci hazırlamak üzere eğitim veren Bahriye Rüşdiye Mektebi'nde yaklaşık 200 öğrenci bulunmaktaydı. Bu okulun Menşe-i Küttâb-1 Askerî kısmında 1898 yılında 20 öğrenci vardı. Bahriye Mektebi'nde 122 Bahriye Mektebi öğrencisi, 255 Bahriye İdadi Mektebi öğrencisi olmak üzere toplam 377 öğrenci eğitim görüyordu. Leyli Tüccar Kaptan Mektebi’nde 75 öğrenci, 1882 yılında açılan, iki sınıflı Azapkapı'daki neharî Tüccar Kaptan Mektebi'nde ise 18 öğrenci vardı. Selimiye firkateyninde faaliyet gösteren Bahriye Gedikli (Astsubay) Mektebi sekiz sınıftan ibaret olup bunlardan üçü telgraf, beşi ise gedikli sınıflarından teşekkül ediyordu. Burada hepsi

66 DTA, BN, 180/4050. Bahriye Rüşdiye Mektebi Müdürü Ahmed Nazif'ten Bahriye Nezaretine, 15 Eylül 1907.

67 DTA, BN, 180/4050. Mekteb-i Bahriye Nazırı Mustafa Paşa'dan Bahriye Nezareti'ne. 6 Eylül 1908; DTA, BN, 333/11830. Bahriye Nezareti'nden Maarif Nezareti'ne. 24 Eylül 1908.

68 BOA, BEO, 3407/255488. Lef 1. Sadaret'ten Bahriye Nezareti'ne. 29 Eylül 1908; BOA, BEO, $3407 / 255488$. Lef 2. Kasımpaşa Bahriye Rüşdiye talebesi adına Sadaret'e gönderilen arzuhal, 26 Ağustos 1908.

69 Ergin, s. 1182. 
Müslüman olmak üzere toplam 93 öğrenci vard1 ${ }^{70}$. Tersâne-i Âmire dâhilindeki Leylî Makine Ameliyat Mektebi’nde 11 sınıftan mürekkep dersliklerde öğrenciler gündüzleri fabrikalarda iş ile akşamları ise ders ile meşgul oluyorlardı. Tahsilini tamamlayanlar çarkçı mülâzım-ı evvel rütbesiyle mezun oluyordu. Bu okuldaki öğrencilerin hepsi Müslüman olup toplam 1.250 kişiden ibaretti ${ }^{71}$. Yine Tersâne-i Âmire dâhilinde Bahriye Sanayi ve İmalat-1 Sibyan Tabur-1 Hümâyûnları Mektebi'nin sanayi ve imalat kısımları iki taburdan ve beş sınıftan ibaret olup hepsi Müslüman olmak üzere 438 öğrencisi vardı. Bu okul, Çarkçı Ameliyat Mektebi ile Bahriye Sanayi Alayı'na ve Sıbyan Musikasına öğrenci hazırlıyordu. Diğer yandan Bahriye Merkez Hastanesi dâhilinde 1895 yılında açılan Eczacı ve Tımarcı Sıbyan Mektebi de beş sınıf üzere mevcut olup buradan bahriyenin ihtiyacı olan eczacı ve cerrahlar

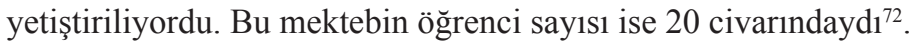

Yukarıda öğrenci sayıları hakkında bilgi verilen başta Heybeliada' daki Bahriye Mektebi olmak üzere; Bahriye Rüşdiyesi, Çarkçı Ameliyat Mektebi, Tüccar Kaptan Mektebi, Bahriye Gedikli Mektebi, Bahriye Sanayi ve İmalat-1 Sıbyan Taburu gibi okullar bahriyeye nitelikli personel temin etmek amacıyla açılmışlardı. Bahriye Rüşdiyesi de askerî eğitimde çağdaşlaşma yolunda bahriyenin üst sınıflarında eğitim görecek iyi yetişmiş öğrencileri hazırlama amacıyla açılmıştı ve bu işlevini uzun yıllar boyunca yerine getirdi.

\section{Sonuç}

Avrupa için eğitim çağı olarak nitelendirilen 19. yüzyıl, Osmanlılar için de bu sahada birçok atılımın yapıldığı bir dönem olmuştur. Savaş meydanlarında alınan başarısızlıkların, silah, teçhizat ve donanım eksikliğinin bu alanda yetiştirilecek nitelikli insan gücü ile telafi edilebileceğini gören Osmanlı idarecileri modern askerî okulların açılması yönünde karar almışlar ve bunu icraata da geçirmişlerdir. Deniz ve Kara harp okullarına nitelikli öğrenci yetiştirilmesi maksadıyla askerî idadiler ve daha sonra da askerî rüşdiyelerin açılması da askerî eğitimin modernleşmesi yönünde önemli katkılar yapmıştır. Öğrenci sayısı yıllara göre değişse de ortalama 250-400 arasında bulunan ve 33 yıl hizmet veren Kasımpaşa Bahriye Askerî Rüşdiyesi de Osmanlı İstanbul'unda modern mesleki eğitim veren askerî eğitim kurumları arasında yer almıştır. İdarecilerinin ve eğitimcilerinin asker olduğu, yabancı dil olarak İngilizcenin okutulduğu bu mektepten askerî disiplin içinde öğrenciler yetiştirilmiştir. Bahriyelilerin semti olarak bilinen Kasımpaşa'da ikamet eden başta bahriye mensubu aileler çocuklarının rüşdiye eğitimi için genellikle bu okulu tercih etmişlerdir. Böylece bazı ailelerde babadan oğula geçen bahriyeli olma geleneğinin devamı sağlanmıştır.

70 Salnâme-i Nezaret-i Maarif-i Umumiye, Matbaa-i Âmire, sene 1316, s. 737, 739-740, 743.

71 Salnâme-i Nezaret-i Maarif-i Umumiye, Matbaa-i Âmire, sene 1316, s. 739. Aynı okulda 1903 yılında; makine sınıfı 508, idadi sınıfı 847 ve ibtidai sınıfı 72 olmak üzere toplam 1.828 öğrenci mevcuttu. Salnâme-i Nezaret- $i$ Maarif-i Umumiye, Matbaa-i Âmire, sene 1321, s. 242.

72 Salnâme-i Nezaret-i Maarif-i Umumiye, Matbaa-i Âmire, sene 1316, s. 742-743. 
Bahriye Rüşdiyesi'nden mezun olanların çoğu Heybeliada'daki Bahriye Mektebi'nin önce idadi sınıfına, oradan mezun olduktan sonra aynı okulun harbiye sınıfına geçiş yapmışlardır. Bahriye Rüşdiyesi'nden mezun olanlardan bir kısmı da aynı okul içerisinde açılan Menşe-i Küttâb sınıfına gönderilmiş ve bahriyenin kâtip ihtiyacı da buradan karşılanmıştır. Bahriye Rüşdiyesi, Türk eğitim tarihinde askerî rüşdiyeler içerisinde ilk ve tek askerî bahriye rüşdiyesi olma özelliğiyle ayrı ve özel bir yere sahip olmuştur. Bahriye Rüşdiyesi Mektebi’nin binası günümüzde Milli Eğitim Bakanlığı'na bağlı bir eğitim kurumu olarak yeni öğrenciler yetiştirmeye devam etmektedir.

Hakem Değerlendirmesi: Dış bağımsız.

Çıkar Çatışması: Yazar çıkar çatışması bildirmemiştir.

Finansal Destek: Yazar bu çalışma için finansal destek almadığını beyan etmiştir.

Peer-review: Externally peer-reviewed.

Conflict of Interest: The author has no conflict of interest to declare.

Grant Support: The author declared that this study has received no financial support.

\section{Kaynakça/References}

\section{Arşiv Kaynakları}

\section{Cumhurbaşkanlığı Devlet Arşivleri Başkanlık Osmanlı Arşivi (BOA)}

Sadaret Âmedi Kalemi Evrakı (A.AMD): 28/51.

Bâbıâli Evrak Odası (BEO): 3407/255488.

Maarif Nezareti Mektubi Kalemi (MF.MKT): 100/56.

Y1ldız Tasnifi Perakende Askeri Maruzat (Y.PRK.ASK): 36/99.

\section{Deniz Tarihi Arşivi (DTA)}

Bahriye Nezareti Yoklama Kalemi Zâbitan Künye Defteri: 31/21, 242.

Bahriye Nezareti Sicill-i Ahval Evrakı (BH.SAID): 18916/135.

Bahriye Nezareti (BN): $\quad 180 / 4050 ; 181 / 4063 ; 333 / 11830$.

Erkân-1 Harbiye-i Bahriye Dairesi Defterleri (EHB.d): 9/18.

Islahat Komisyonu: 227/17.

Meclis-i Bahriye Defterleri (MB.d): 115/59, 105.

Bahriye Nezareti Mektubi Kalemi Defterleri (MKT): 11/3; 241/33; 360/26; 377/80; 380/44; 403/13; 412/81; $685 / 186 ; 729 / 5$.

Bahriye Muhasebe Kalemi (MUH): 670/5; 664/30; 664/44.

Şura-y1 Bahriye Defterleri (ŞUB.d): 16/32; 24/97; 26/4; 98/76; 101/34; 104/78, 106/96; 226/47; 273/9; $498 / 101$.

Fotoğraf Arşivi, Fotoğraf No. 1221. 


\section{Yayınlanan Kaynaklar}

Akyüz, Yahya, Türk Eğitim Tarihi, 5. Baskı, Türk Koleji Yayınları, İstanbul 1994.

Alkan, Mehmet Ö., Tanzimat’tan Cumhuriyet'e Modernleşme Sürecinde Eğitim Ístatistikleri 1839-1924, c. VI, T.C. Başbakanlık Devlet İstatistik Enstitüsü Yayınları, Ankara 2000.

Altınova, Ayşegül, Osmanlı Modernleşmesinde Rüşdiye Mektepleri, Gazi Ünv. Sosyal Bilimler Enstitüsü, Basılmamış Doktora Tezi, Ankara 2010.

Başaran, Serdar - Levent Düzcü, Osmanlı'dan Cumhuriyet'e Denizciler: Yelkenli ve Buharlı Çă̆ın Emektarlarl, Kriter Yayınevi, İstanbul 2016.

Beydilli, Kemal, Türk Bilim ve Matbaacılı Tarihinde Mühendishâne: Mühendishâne Matbaası ve Kütüphânesi (1776-1826), Eren Yayınc1lık, İstanbul 1995.

Çoker, Fahri, Bahriye Mektebimiz, DZKK. Yayınları, Ankara 1973.

Ergin, Osman, Türkiye Maarif Tarihi, c. II, Osmanbey Matbaası, İstanbul 1940.

Eyüb Sabri Paşa, Mir'âtü'l Haremeyn, Cilt 1-2 (Inceleme-Metin), haz. Ömer Fâruk Can-F. Zehra Can, Türkiye Yazma Eserler Kurumu Başkanlığı Yayınları, İstanbul 2018.

İgüs, Esma, II. Abdülhamid Dönemi Eğitim Sistemi, Eğitim Yapıları ve Askerî Rüşdiyeler, Mimar Sinan Güzel

Sanatlar Üniversitesi, Fen Bilimleri Enstitüsü Mimarlık Tarihi ve Kuramı Doktora Programı, Basılmamış

Doktora Tezi, İstanbul 2008.

İpşirli, Mehmet, "Mahreç”, DİA, c. XXVII, İstanbul 2003, s. 388.

İstanbul Teknik Üniversitesi ve Mühendislik Tarihimiz, ed. Mehmet Karaca, haz. Mustafa Kaçar, Tuncay Zorlu, Burak Barutçu, Atilla Bir, C. Ozan Ceyhan, Aras Neftçi, İTÜ Vakfı Yayınları, İstanbul 2013.

Kaçar, Mustafa, Osmanlı Devleti’nde Bilim ve Eğitim Anlaylşındaki Değişmeler ve Mühendishânelerin Kuruluşu, İstanbul Üniversitesi Sosyal Bilimler Enstitüsü, Basılmamış Doktora Tezi, İstanbul 1994.

Kenan, Seyfi, “Türk Eğitim Düşüncesi ve Deneyiminin Dönüm Noktaları Üzerine Bir Çözümleme”, Osmanlı Araştırmaları, sayı 41 (2013), s. 1-31.

Korkmaz, Mehmet, "Yakınçağ Tarih Araştırmalarında Deniz Tarihi (Bahriye) Arşivi’nin Önemi”, 2. Uluslararası Osmanlı Coğrafyası Arşiv Kongresi, Bildiriler, c. II, T.C. Çevre ve Şehircilik Bakanlığı Tapu ve Kadastro Genel Müdürlüğü Yayınları, Ankara 2019, s. 751-769.

Kurtoğlu, Fevzi, Deniz Mektepleri Tarihçesi, İstanbul Deniz Matbaası, İstanbul 1941.

Mehmed Esad, Mir'ât-ı Mekteb-i Harbiye, Artin Asaduryan Şirket-i Mürettibiyye Matbaası, İstanbul 1310. , Mir'ât-ı Mühendishâne-i Berrî-i Hümâyûn, Karabet Matbaası, İstanbul 1312.

Patoğlu, Emrah Berkant, Osmanlı Devleti’nde Askerî Rüştiyeler, Gaziantep Üniversitesi Sosyal Bilimler Enstitüsü, Basılmamış Doktora Tezi, Gaziantep 2018.

Rıza Tahsin, Tıp Fakültesi Tarihçesi (Mir'ât-ı Mekteb-i Tıbbiye), c. I-II, eklerle yay.haz. Aykut Kazancıgil, Özel Yayınları, İstanbul 1991.

Somel, Selçuk Akşin, Osmanlı'da Eğitimin Modernleşmesi (1839-1908), İletişim Yayınları, 2. Baskı, İstanbul 2015.

Türkmen, Zekeriya, "Sultan Abdülaziz Döneminde Süvari Kışlasından Askerî İdadiye Dönüşüm Sürecinde Kuleli”, XVII. Türk Tarih Kongresi Bildirileri, 15-17 Eylül 2014, Ankara, c. IV/1. Kısım, TTK Yay., Ankara 2018, s. 79-104. 
Umum Mekâtib-i Rüşdiyeye Mahsus Olarak Bu Kere Ta'dilen Tertip Edilen Ders Programıdır, Matbaa-i Âmire, Dersaadet 1315 .

Ünal, Uğur, II. Meşrutiyet Öncesi Osmanlı Rüşdiyeleri (1897-1907), TTK. Yayınları, Ankara 2015.

Ünlü, Rasim, Deniz Lisesi Tarihçesi, b.y.y. t.y.

Yarar, Hülya, Osmanlı Döneminde Askerî Okullarda Eğitim, Milli Savunma Bakanlığı Yayınları, TTK Basımevi, Ankara 2000.

\section{Süreli Yayınlar}

Ceride-i Askeriye.

Ceride-i Bahriye.

Ruznâme-i Ceride-i Havâdis.

\section{Salnâmeler}

Bahriye Salnamesi, Ondördüncü Def’a, Matbaa-i Bahriye, Dersaadet 1321.

Salname-i Bahrî, Birinci Def'a, Matbaa-i Bahriye, Dersaadet 1307; İkinci Def'a, Matbaa-i Bahriye, Dersaadet 1308; Dördüncü Def’a, Matbaa-i Bahriye, Dersaadet 1311.

Salnâme-i Nezaret-i Maarif-i Umumiye, Matbaa-i Âmire, Dersaadet 1316; Dersaadet 1321. 


\section{EK}

\section{Kasımpaşa Bahriye Askerî Rüşdiye Mektebi Önünde Öğrenciler}

Fotoğrafin altında "Sâye-i Maârif-vâye-i Hazret-i Pâdişâhîde Müceddeden İşa Olunan Mekteb-i Rüşdiye-i Asâkir-i Bahriye" yazısı yer almaktadır.

Kapının Üzerindeki Kitâbede de "Mekteb-i Rüşdiye-i Asâkir-i Bahriye" ibaresi bulunmaktadır.

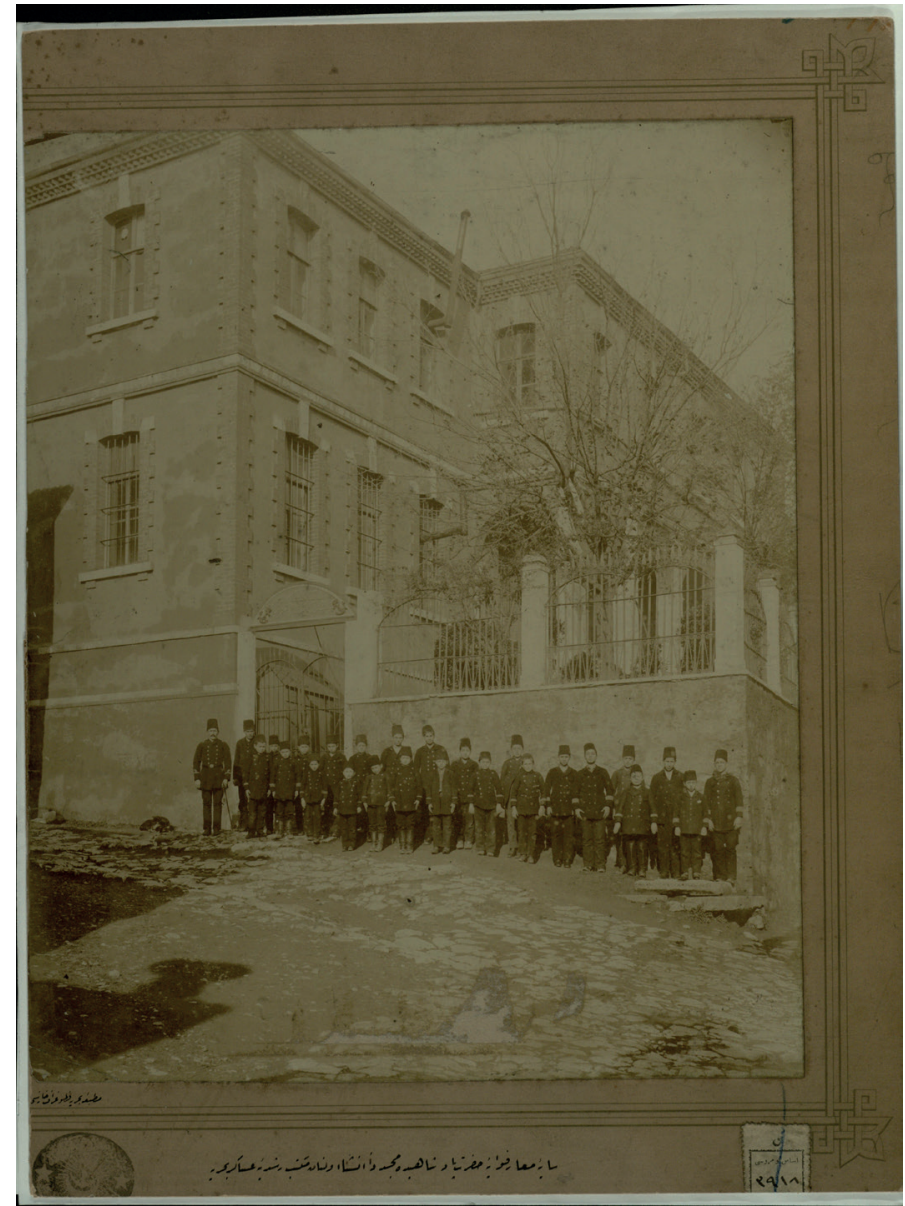

(Kaynak: Deniz Müzesi, Fotoğraf Arşivi, Fotoğraf No. 1221). 
